\title{
New mammalian remains from the Late Cretaceous La Colonia Formation, Patagonia, Argentina
}

Guillermo W. Rougier, Analía M. Forasiepi, Robert V. Hill, and Michael Novacek Acta Palaeontologica Polonica 54 (2), 2009: 195-212 doi:http://dx.doi.org/10.4202/app.2006.0026

Knowledge of the latest Late Cretaceous mammalian fauna in the South America was, until now, mostly based on dentally known taxa recovered at Los Alamitos (Río Negro, Argentina). Here we describe new mammalian remains collected in outcrops of the La Colonia Formation (Campanian-Maastrichtian) exposed in Chubut Province, Argentina, warranting the recognition of a new mesungulatid: Coloniatherium cilinskii gen. et sp. nov. The mammalian high-level taxonomic compositions of the localities in the La Colonia Formation and at Los Alamitos are roughly similar (Reigitheriidae, Mesungulatidae, and Ferugliotheridae are represented in both localities), but gondwanatheriids and the more plesiomorphic dryolestoids from Los Alamitos are missing from La Colonia. The most abundant mammalian remains collected at La Colonia correspond to large-sized mesungulatids. Coloniatherium cilinskii is recognized by the dentition and lower jaw, and we assign five isolated petrosal bones, focusing our study primarily on the analysis of the ear regions. The morphology of the petrosals suggests a phylogenetic position similar to Vincelestes, but sharing some derived features, possibly convergent, with therians. Attribution of the petrosals to the mesungulatid Coloniatherium cilinskii is supported by overall morphology, size, and relative abundance among the mammalian remains from La Colonia.

Key words: Mammalia, Mesungulatidae, CAmpanian-Mastrichtian, Cretaceous, La Colonia Formation, Argentina.

Guillermo W. Rougier [grougier@louisville.edu], Department of Anatomical Sciences and Neurobiology, University of Louisville, Louisville KY 40292 , USA; Analía M. Forasiepi [borhyaena@hotmail.com], Sección Paleontología, Museo de Historia Natural de San Rafael. Parque Mariano Moreno s/n, CP. 5600, San Rafael, Mendoza, Argentina; Robert V. Hill [rhill01@nyit.edu], Department of Anatomy, New York College of Osteopathic Medicine, New York Institute of Technology, Old Westbury, NY 11568, USA; Michael Novacek [novacek@amnh.org], Division of Paleontology, American Museum of Natural History, 79th St. at Central Park West, New York, NY 10024 USA. 
This is an open-access article distributed under the terms of the Creative Commons Attribution License (for details please see creativecommons.org), which permits unrestricted use, distribution, and reproduction in any medium, provided the original author and source are credited.

Farif Full text $(546.8 \mathrm{kB})$ 